\title{
Research on the Development of Securities Industry and the Annual Report of 27 Listed Brokerages in 2016
}

\author{
Jia Liu \\ Institute of Economics and Management \\ Tianjin University of Technology and Education \\ Tianjin, China
}

\author{
Xuexin Wang \\ Institute of Economics and Management \\ Tianjin University of Technology and Education \\ Tianjin, China
}

\begin{abstract}
The securities market is an important part of financial system in Chin, which has irreplaceable functions in raising capital, guiding investment and allocating resources. After 20 years of development, China's securities market from establish to integration, from the experience of the global financial crisis test to further innovation and development, the market is growing, entered the norms and healthy development in the new period. However, with the completion of the reform of the equity separation and the outbreak of the global financial crisis, the profit model and the development pattern of securities companies have had a significant impact. After the financial crisis, global financial markets in turmoil, risk concentration, the plunging stock market, make the competition between Chinese securities firms, the problems existing in the profit model is highlighted. This article from the assets of the securities industry, revenue, business structure, and the two cities about four aspects: comb the securities industry as a whole operation, review priorities as the capital markets in recent years, combined with 27 listed securities brokerage sector performance in 2016 annual report analysis, income and assets and liabilities.
\end{abstract}

Keywords-securities market; afraid of listed securities firms; income; structure

\section{INTRODUCTION}

The total of 27 listed brokerages totaled 260717 billion yuan in 2016, with net income of 926.71 billion yuan, accounting for $79.49 \%$ and $75.07 \%$ respectively. According to the securities industry association, according to data released in 2016, total assets of 5.79 trillion yuan, 129 securities companies with a net worth of 1.64 trillion yuan, net capital is 1.47 trillion yuan, achieve business income is 327.994 billion yuan, the cumulative net profit of 123.445 billion yuan. In the pattern of market volatility, the business performance of securities firms has fallen sharply from 2015, and investment banking, capital management and credit businesses have become more prominent in the income structure of brokerages.

\section{THE OVERALL OPERATION OF THE SECURITIES INDUSTRY}

\section{A. Assets}

In 2016, the capital market continued to oscillate, the Shanghai and shenzhen exchanges were cold, the stock market volatility fell and the main business declined to a certain extent to restrain the asset expansion impulse. The total assets of the securities industry in 2016 were 5.79 trillion yuan, down 9.81 percent year on year. Net assets of 1.64 trillion yuan, a year-on-year increase of $13.10 \%$; Net capital was 1.47 trillion yuan, up $17.6 \%$ year on year.

In 2016, the total assets of the whole industry shrank, but the net asset size rose, reflecting the 2016 concussion market. At the same time, it also shows that the financing power and demand decline of the securities firms, the financial leverage ratio remains stable, and the large debt is not sufficient.

The industry net capital of 14700 yuan in 2016, after a $84.05 \%$ jump in 2015 , a $17.6 \%$ growth again, shows that despite the regulatory environment and market environment changes, brokerage, added the external requirements of the net capital and endogenous power remain. In late 2014, the securities and futures commission, the securities industry association has issued the notice about encouraging securities companies to further supplementary capital, "about a securities company shall submit supplementary capital planning related work notice, require the securities company shall replenish capital at least once in the next three years, is still in the validity period of three years added in 2016. In addition, in June 2016, the adjustment of the securities company risk control management measures ", has been clear about the core position of net capital, again to continue to the index and brokerage business scale, business scope, risk control, improve the net capital calculation rules and application at the same time, the net capital purposes better return to nature. For securities companies, the expansion of capital remains the basis and guarantee for securities companies to improve their business structure, expand their business scope and enhance their ability to withstand risks. 


\section{B. Revenue Situation}

In 2016, the whole industry of securities companies realized operating revenue of 327.994 billion yuan, down 42.98 percent year on year. Net profit was 1234.45 billion yuan, down 49.59 percent year on year. Securities industry revenue and profit due to a sharp fall in profits tied to stock market volatility, volatility of capital market in 2016, the dominant position of brokerage revenues brokerage business income has fallen dramatically, proprietary business profitability pressure increases, securities lending and borrowing business scale caused by shrinkage.

In terms of asset structure and profitability, the equity multiplier was reduced from 4.43 in 2015 to 3.53, indicating a downward trend in industry consolidation. Net interest rates fell to 37.62 per cent from 42.56 per cent in 2015 , indicating a decline in the sector's ability to organize profitability. The decline in leverage and profit margins also contributed to the decline in ROE, which fell sharply from 16.88 per cent in 2015 to 7.52 per cent.

\section{Business Structure Situation}

From the main business income structure of the securities firm, the brokerage business income in 2016 was 1052.95 billion yuan, down $60.87 \%$ year on year, accounting for $32.10 \%$ of total business revenue. Investment banking revenue was 519.99 billion yuan, up 31.98 percent year on year, accounting for $15.85 \%$ of total revenue. Revenue from asset management was 29.646 billion yuan, up 7.64 percent year on year, accounting for $9.02 \%$ of total business revenue. Revenue from proprietary business was 56.847 billion yuan, down $59.83 \%$ year on year, accounting for $17.32 \%$ of total revenue. Interest income was 38179 million yuan, down 35.36 percent year on year, accounting for 11.65 percent of total business revenue.

From the income structure of the securities company, the brokerage business of securities companies is the most obvious in the two cities. In addition, the average commission rate of the industry dropped from 4.99 in 2015 to 4.03, making the brokerage business of securities companies worse. Investment banking, although the regulation strictly, but the capital market reform trend, IPO, refinancing rate continue to ascend, m\&a market active, brokerage, investment banking revenues contrarian ascension. Asset management business income is stable, but in the second half of 2016 to the first half of this year, a series of regulations that brokers information technology, aimed at reducing leverage, to channel mismatch, prohibited pool, reduce time limit, the brokerage could compliance pressure increase in the future. Proprietary business is subject to the performance of the two markets, the overall revenue downturn. In terms of credit business, margin growth is weak, and the stock pledge business becomes an important source of credit business income.

\section{The Transaction of the Two Markets}

In 2016, the average daily volume of the Shanghai and shenzhen exchanges was 38433 million shares, down $44.58 \%$ year on year. Daily turnover was 517.997 billion yuan, down $50.04 \%$ from the previous year. At the beginning of the
Shanghai composite index and shenzhen stock exchange component by 3536.59 points and 12650.72 points respectively, affected by fusing rally opening in the a-share market opened years' experience volatility, the Shanghai index fell below 2638.80 in January, dropped below 8986.52 in shenzhen, after the market into A tight range stage, the downturn in the two city trading market is active degree of apathy, market structure stability is not enough, will seriously affect securities brokerage and proprietary trading company.

\section{CAPITAL MARKET Highlights REVIEW}

\section{A. Risk Regulation is Regularized}

In 2015, due to the high leverage, the market caused a huge earthquake, which led to a higher risk of financial system. In early 2016, the market had a continuous one-sided decline, causing market panic. Regulators in view of the problems existing in the financial markets in 2016 to strengthen risk management, release all kinds of regulation more than 20, 218 issued by the administrative punishment book, involving securities companies, fund companies, fund subsidiary, futures companies and related listed companies, was carried out on the market, comprehensive, strictly in accordance with the regulation, to pay attention to curb excessive speculation, to guide the healthy development of the market. The strength of the regulatory policy in 2016 is rare, and the strong regulatory momentum continues in 2017 , with tighter regulation and tighter regulation becoming a trend.

\section{B. The Risk Management Index System was Revised}

On June 17, 2016, the CSRC published the revised measures for the management of risk control indicators of securities companies and was implemented in October 2016. Compared with previous measures of risk supervision, there are six core changes: one is to improve the net capital and the calculation formula of risk capital. The second is to improve the index of leverage ratio and improve the completeness of risk coverage. Third, we will optimize liquidity monitoring indicators and strengthen the term of balance of assets and liabilities. Fourth, improve the risk control index of single business and improve pertinence; Fifth, it is clear countercyclical adjustment mechanism to improve the effectiveness of risk control. Sixth, strengthen the comprehensive risk management requirements and improve the risk management level. New regulatory index system more inclined to the securities industry faces new challenges, in the process of actual operation for the healthy development of the industry in the new period, also will speed up the differentiation of the industry, push broker to build solid health risk system.

\section{Adjustment of the Classification Results of Securities Brokers}

On July 15, 2016, the China securities regulatory commission announced 2016 securities companies classification rating as a result, 125 brokerages involved in regulatory classification evaluation, the actual evaluation subject for 95, brokerage, a total of 58, classification downgrade classification upgraded brokers only seven. Citic 
securities, haitong securities, guangfa securities, huatai securities and guosen securities were relegated to category B securities, and the industry suffered the most severe regulatory classification adjustment in history. Securities regulatory classification results focus on the investigation and compliance risk management ability, risk of brokerage prepare provisions, open a new branch, access to new business and insurance funds to pay also can produce certain influence. In 2016, the adjustment of the supervision and classification results of securities dealers is also the performance of supervision, and the situation of risk control and evaluation will be the main theme for a long time in the future.

\section{The Reorganization of the Listing Regulation is Strict}

On June 17, 2016, the measures for the administration of material assets reorganization of listed companies (revised) for public opinion, revised perfected the restructuring listed prior access conditions, regulating the behavior of the reorganization of the listed from the source. Considering investment banking revenues in the brokerage, comprehensive income structure overall proportion is not high, restructuring listed threshold tighter influence on brokerage sector income is limited, and the long term the regulation will curb speculation "shell" behavior, the escort for the healthy development of the market stable.

\section{E. The New Three-board Tiered Mechanism Lands}

National small and medium-sized enterprise stock transfer system co., LTD in May 2016, issued the national small and medium-sized enterprises listed company stock transfer system hierarchical management approach (trial) ", on June 27, clear the new three board market will formally implement layered management of listed company. The "layered approach" proposes five common standards for innovation tier listed companies, including the company's nearly 12 months 'financing scale, the clear standard of the number of transactions in 60 days and other compliance requirements. Three sets of differentiation standard requirements to the company net profit, operating income and market value, respectively to measure the company's profitability, growth and business model, is required to meet the company for one of the three kinds of standards. In addition to the entry criteria, the layered method "also set up three sets of the innovation of new three board layer to maintain standards, layers of innovation in April every year the company to adjust, and can't meet one of the three sets of maintaining standards will be transferred to the base layer. After entering into enterprise innovation layer, we can enjoy popularity, finance, trade policy dividends, the advantages of the liquidity boost, but also achieve information disclosure, staffing, and restricted management, to raise funds to accept more stringent requirements.

\section{F. The Leverage Multiple of the Asset Management Business has been Tightened}

Association of securities investment fund, revision of the securities and futures business institutions to carry out the asset management business "eight line under the regulations prohibited behavior", a sharp tightening could plan leverage limits, including stock, mixed leverage asset management plan shall not be more than 1 times; The leverage multiple of the equity asset management plan established for the management of the regulated employee ownership plan shall not exceed 2 times; The leverage of futures, fixed income and non-standard asset management plans shall not exceed three times; The leverage of other asset management plans must not exceed 2 times. The revision is conducive to the healthy development of the securities market and to reduce the market fluctuation caused by unsystematic risks, which will protect the interests of investors and safeguard the industrial production period. You can expect the channel class business space to be further compressed. In order to seek long-term core competitiveness, the brokerage business or return to the source, from "passive" channel business to "active" asset management.

\section{THE Business PERFORMANCE OF LISTED SECURITIES BROKERS}

\section{A. Overview of Operating Performance}

In 2016, the number of listed securities companies expanded from 23 to 27 in 2015, with four new ones, including galaxy securities, first venture securities, zhongyuan securities and hua 'an securities. The total operating income of the 27 listed securities firms totaled 26, 0717 billion yuan, a year-on-year decline of $39.83 \%$, accounting for $79.49 \%$ of the total industry. Net profit totaled 926.71 billion yuan, down 48.64 percent year on year, accounting for 75.07 percent of the total industry. The top 10 listed brokerages totaled 191.72 billion yuan, with a net profit of 699.3.2 billion yuan, accounting for 58.25 percent and 56.65 percent of the total industry respectively. The concentration ratio was slightly higher than that of 2015. In 2016, the net capital return of the listed securities companies was $7.98 \%$, down $13.23 \%$ from 2015 and a sharp decline in profitability.

\section{B. The Composition of Operating Income}

In 2016, the net fee and commission net income of the 27 listed securities firms totaled 15.927 billion yuan, accounting for $58.68 \%$ of the total revenue. Net interest net income totaled 28.11 billion yuan, accounting for $11.09 \%$. Net income of investment reached 760.82 billion yuan, accounting for $29.19 \%$. The net income of fair value change, exchange profit and loss and other income totaled 2.7 billion yuan, accounting for $1.04 \%$. Through the above data shows that in recent years, though, the securities company credit, innovation, business development, but the nature is still the capital market intermediaries, the most important source of income is still not fee and commission income; The securities market risk, credit risk, liquidity risk control requirements of higher investment income, interest income in the brokerage business plan into the overall account for the relatively small, the securities industry overall risk control. 


\section{THE INCOME STRUCTURE OF LISTED SECURITIES FIRMS}

\section{A. An Overview of the Income Structure of the Municipal Brokers}

In 2016, the income structure of 27 listed securities firms is embodied in the development of the investment banking industry, the development of the capital management, the steady development of the capital management, the decline of the brokerage business, the serious failure of the proprietary business, and the obvious decline in the credit business. Compared with 2015, brokerage, investment banking has rapidly increased, and steady development of information technology business, both a 2016 brokerage revenue important sources, brokerage and proprietary trading by the cycle characteristics and the rate of commission narrowed and the effect of a sharp decline, two business overall stability, stock pledge to increase business. The above structure is partly a reflection of the volatility of capital markets in 2016, the double death of the stock market at the end of the year, the continued frosty trading volume, the tightening of financial regulation and the convergence of the big events.

\section{B. Brokerage Business}

Under the influence of Internet finance, the competition of traditional brokerage business increased, and the overall commission rate of securities dealers continued to decline, from 5 PPM in 2015 to 4 PPM in 2016. At the same time, the Shanghai and shenzhen two city trading volume shrunk dramatically, compared to the average daily volume of 38.433 billion shares, the two cities fell by $44.58 \%$, to 2015 brokerage business amount of premium, clinch a deal amount to day hedge brokerage commission rate decline patterns to continue. Total brokerage revenue of 27 listed brokerages totaled 110.669 billion yuan in 2016 , down $51.18 \%$ year on year.

\section{Proprietary Trading}

The brokerage business has moved with the market, and in the volatile market for capital markets in 2016; it has been a major downturn in the sector after the brokerage business. As a period of highly dependent market, the proprietary business benefited from the leveraged bull market in 2015, which brought rich profits to brokerages and enjoyed the dividend of the bond market. The twin killings of 2016, two breakpoints at the beginning of the year and the return of the bond market at the end of the year have brought a heavy blow to the brokerage's proprietary business. In 2016, the total proprietary business income of the 27 listed securities companies was 38.222 billion yuan, accounting for 12.25 percent, down 59.01 percent from the same period last year.

\section{Investment Banking}

The rapid growth of investment banking has become a bright spot for the main business of listed brokerages in 2016 . In 2016, the IPO volume of the a-share market was 149.6 billion yuan, down 5\% year-on-year. The refinancing scale was 1721.7 billion yuan, up $40 \%$ year-on-year. In the fourth quarter of 2016, regulation accelerated the pace of IPO issuance, released good expectations and expected IPO financing to expand further in 2017.

\section{E. Information Technology Business}

The rapid growth of investment banking has become a bright spot for the main business of listed brokerages in 2016. In 2016, the IPO volume of the a-share market was 149.6 billion yuan, down 5\% year-on-year. The refinancing scale was 1721.7 billion yuan, up $40 \%$ year-on-year. In the fourth quarter of 2016, regulation accelerated the pace of IPO issuance, released good expectations and expected IPO financing to expand further in 2017.

\section{F. The Credit Business}

After the 2012 brokerage innovation conference, the securities companies gradually transformed into the capital intermediary business, and the credit business developed greatly. The credit operations of brokerages mainly include margin trading business, stock pledge business, and the fixed repurchase business, which is relatively small in the income structure.

In 2016, influenced by the market environment, investors' willingness to raise funds was reduced. In 2016, the average daily balance of the margin of the market margin was 898.2 billion yuan, down $35 \%$ year on year. At the end of the year, the balance of margin financing of the 27 listed securities companies was 655.5 billion yuan, down 20.34 percent yearon-year. The scale of margin financing is similar to the brokerage business, which is highly correlated with market fluctuation. In the case of a single broker, its margin business volume is positively correlated with the strength of the brokerage business, mainly the high net value of the brokerage business.

\section{THE ASSETS AND LIABILITIES OF THE LISTED BROKERAGE}

\section{A. Overview of Assets and Liabilities of Listed Securities Companies}

In late 2016, 27 listed securities firms total assets of 4.81 trillion yuan, net assets of 1.15 trillion yuan, 881.616 billion yuan net capital, growth to $7.46 \%, 7.46 \%$ and $9.84 \%$, respectively, affected by the 2016 capital market, the listed securities have lower debt leverage is applied, the sheets remain stable, debt amounted to 3.67 trillion yuan in 2015, down $11.55 \%$ year-on-year. From stock size concentration data, industry competition pattern basically stable, before 2016 , total assets, net assets, net capital five listed brokerage industry concentration ratio (CR5) were $48.49 \%, 47.45 \%$, $42.24 \%$, from 2015 fell by $4.17 \%, 6.49 \%$ and $9.25 \%$ respectively.

\section{B. Assets}

The total assets of the 27 listed securities firms totaled 4819.90 .37 billion yuan, a decline of $7.46 \%$. The total assets of listed brokerages totaled 3896955 billion yuan, or 0.75 percent, after deducting the customer funds deposit. Among them, the total amount of customer funds was 922982 million yuan, down $27.24 \%$ year on year, accounting for $18.15 \%$. In addition to the customer's capital deposit, the total amount of the remaining money was RMB 3001.40 billion, a year-on- 
year decline of $14.77 \%$, accounting for $6.23 \%$. The total financial assets of the current profit and loss of the fair value measured in the current profit and loss totaled 8839.9 billion yuan, down $10.00 \%$ year on year, accounting for $18.55 \%$. The total amount of derivative financial assets totaled 10.377 billion yuan, down $43.35 \%$ year on year, accounting for $0.22 \%$. The total amount of purchase and resale financial assets totaled 5535.00 billion yuan, up 41.73 percent year-on-year, accounting for 11.48 percent. The sale of financial assets totaled 7119.89 billion yuan, up $9.27 \%$ year on year, accounting for 14.77 percent. In total, the total investment was 432.47 billion yuan, up $33.15 \%$ year on year, accounting for $0.90 \%$. As a whole, the asset structure of the 27 listed securities firms is stable.

From the balance sheet asset class, the main reason for the decrease of customer deposits is the impact of the capital market in 2016. The main reason for the decline of trading financial assets is the decrease in the size of listed securities investment, wealth management products and funds. The decline in derivative financial assets is mainly in interest rate swaps and off-market options. The purchase of resale of financial assets is mainly the increase of the financial assets of the stock pledge class in 2016. The increase in the sale of financial assets is mainly for non-derivative financial assets to be sold, such as bond investment and direct investment.

\section{Liabilities}

The total liabilities of the 27 listed brokerages totaled 3669.105 billion yuan, a decline of $11.55 \%$. Total assets of listed securities firms totaled 389,695 billion yuan, a decline of $0.75 \%$. Among them, the total amount of acting securities and buying and selling securities totaled 11553.03 billion yuan, down $24.57 \%$ year on year, accounting for $31.49 \%$ of the total Short-term borrowings totaled 77.379 billion yuan, up 47.49 percent year on year, accounting for 2.11 percent. The total amount of the funds was 833.13 billion yuan, up $31.57 \%$ year on year, accounting for $2.27 \%$. Trading financial liabilities totaled 179.357 billion yuan, up 49.82 percent year on year, accounting for 4.89 percent. The total amount of the repurchase of financial assets was 588.462 billion yuan, a year-on-year decline of $29.99 \%$, accounting for 16.04 percent. The bonds payable totaled 901.91 billion yuan, up 8.96 percent from the previous year, accounting for 24.56 percent. The total compensation payable was 67359 million yuan, down $13.05 \%$ from the previous year, accounting for $1.84 \%$. As a whole, the balance sheet structure of the 27 listed securities firms is basically corresponding to the asset structure.

\section{Net Capital Situation}

At the end of 2016, the net capital of 27 listed brokerages totaled 8816.19 billion yuan, up 10.48 percent year on year. In June 2016, the SFC issued the measures for the administration of securities company risk control indicators, the financial assets into venture capital instead of deducting the net capital, long-term subordinated debt scale into subsidiary net capital, on the basis of the net capital at the end of 2015 industry 2015, after the change of a conservative estimate at least release online net capital size of about 1100-120 billion yuan.

\section{CONCLUSION}

Based on the analysis of the development of the securities industry in 2016 and the analysis of the annual report of 27 listed brokers, this paper summarizes the views of this paper as follows:

- Capital markets continued to oscillate, the Shanghai and shenzhen exchanges were cold, the stock market volatility fell, investors were not confident. The main business of securities firms has been sharply declining, to a certain extent to restrain the securities firms expansion impulse. At the same time, the regulation of the maintenance of the stability of the overall enhancement, the industry development into the depth adjustment period.

- Capital market efficiency enhanced service entity economy, the ipo rhythm in the steady speed, the bond market product innovation breakthrough unceasingly, m\&a market active, brokerage, investment banking benefit development, become the industry bright spot.

- The total assets of the securities industry have been reduced slightly, and the net asset and net capital have continued to rise. Reflecting the market turmoil of 2016, the number of securities firms' operating income decreased and the amount of payment for the settlement was significantly reduced. We will show that the financing and demand of brokerages are falling, the financial leverage ratio remains stable, and we continue to do not have enough momentum of debt. Despite the changes in market environment and regulatory environment, the external demand and internal impetus for the supplementary net capital are still present.

- In terms of the operation of listed securities companies, the overall performance growth trend is obvious, the status of the leading brokers is stable and the industry pattern is stable, which reflects the lack of expansion of the brokerage business in 2016

- management has developed smoothly, the price of the brokerage business has fallen, the proprietary business has suffered serious setbacks and the credit business has declined. Compared with 2015, brokerage, investment banking has rapidly increased, information technology business development, both a 2016 brokerage revenue important sources, brokerage and proprietary trading because of its cycle characteristics and the rate of commission narrowed, a sharp landslides, two business overall stability, stock pledge to increase business.

In short, the development of China's securities industry has experienced excessive expansion and high leverage. At present, China's economic downturn has entered a normal state, and the macro environment is becoming more and more complicated. As financial reforms have started in recent years, increased regulatory policy actively promote transformation of 
regulation, and further improve the system environment of the securities industry of various business, make the competition more fully, to comprehensively deepen reform, open, innovation stage, the development of the securities industry is facing enormous challenges. The securities industry should further improve the level of financial services, to better play to the financial support for the economic structural adjustment and transformation and upgrading, in the process of the securities industry all kinds of business to better serve the real economy function into full play.

\section{REFERENCES}

[1] Xia Ran, Fu Shu Han. Current situation, problems and development countermeasures of securities companies in China $[\mathrm{J}]$. Financial innovation, 2016, (29): 68-69.

[2] Yu Yaping. The development of new normal economy and securities industry in the context of the rule of law [J]. Technology and economy market, 2016, (5): 50-51

[3] Liu Da. Development trends in the securities industry [J]. Chinese and foreign entrepreneurs, 2014, (15): 11-13.

[4] Zhang Liang. Innovation research on profit model of securities industry [D]. Hebei: hebei university of technology, 2015.

[5] Zhang ChenHui, Liu Jifu, Huang Ye autumn. Perfect securities company business scope Broaden the securities industry development space [C]. China securities industry association, innovation and development: proceedings of the Chinese securities industry in 2013. Beijing: China financial economic publishing house, 2013:1180-1187.

[6] Wang Hua. Related research on the development of financial securities in China [J]. Modern economic information, 2014, (5): 300-300.

[7] Zhang Changgao. Research on the major problems and countermeasures in China's financial securities market [J]. Journal of the time finance, 2014, (4X): 132-132.

[8] Zhang Hong. Securities regulatory measures: challenges and countermeasures [J]. Political law BBS, 2015, 33 (4): 129-139.

[9] Dong-fang Li. The independent research of securities regulators and their regulatory powers - and on the legal reform of China's securities regulatory bodies $[\mathrm{J}]$. Political and political law BBS: journal of China university of political science and law, 201735(1): 74-87. 